\title{
Influence of School heads' Leadership Styles on Students' Academic Performance in Public Secondary Schools in Nyamagana District, Mwanza, Tanzania
}

\author{
Upendo John, Demetria Gerold Mkulu
}

Department of Educational Foundation, St. Augustine University of Tanzania, Mwanza, Tanzania

Received: 11 Nov 2020; Received in revised form: 15 Dec 2020; Accepted: 22 Dec 2020; Available online: 31 Dec 2020 (C)2020 The Author(s). Published by Infogain Publication. This is an open access article under the CC BY license (https://creativecommons.org/licenses/by/4.0/).

\begin{abstract}
This study aimed at investigating the influence of leadership styles of heads of schools on students' academic performance in public secondary schools. The study was guided by the following objectives: to determine the influence of laissez-faire leadership style influences students' academic performance and to find out the influence of democratic leadership style influences students' academic performance in public secondary schools. The study adopted the contingency leadership theory as propounded by Fielder (1978). Mixed Methods Research Approach was employed. Simple random, stratified, and purposive sampling techniques were employed giving the total sample size of 111 individuals. The convergent parallel research design was used whereby the researcher mixed quantitative and qualitative data in a single study and analysed the two different components independently, and interpreted the results together. Quantitative were analysed using the Statistical Package for Social Sciences (Version 21.0), while Qualitative data were analysed using open coding to get categories- themes. The study aimed at finding out which leadership styles school heads employed and how they employed them. This partly explained why several students in Nyamagana Districts performed very poorly. The study recommends that the government should deploy school heads that have undergone leadership courses as well as build leadership capacity among those who are already in schools without adequate knowledge on leadership. Also, school heads with credible leadership knowledge should cascade and share it with relevant educational stakeholders.
\end{abstract}

Keywords - School head, Leadership styles, Academic performance, Laissez-faire, democratic.

\section{INTRODUCTION}

This study research was designed to determine the influence of school heads' leadership styles on students' academic performance in public secondary schools in Nyamagana District, Mwanza, Tanzania.

\section{BACKGROUND OF THE STUDY}

In an educational organization, just like in any other organizations, the role of leadership is very crucial. A good leader should make sure that he or she initiates stakeholder inclusively in all key issues and in making decisions. In some situations, leader's informed views may be pushed through in what may seem as force especially when subordinates seem not interested or committed enough. An effective school leadership leads to good school productivity that is good performance of students in national examinations. This is why Nannyonjo (2017) in the study on building capacity of school leaders in Jamaica observes that appropriate leadership style by heads of schools can impact 
positively on learner's outcome. He concludes that the school head plays a pivot role about which realization of institutional goals hinges.

The issue of school leadership has been a debate among scholars worldwide. School leaders have been blamed of being the major cause of students' poor academic performance. Different researchers around the world have been continuously investigating on if it is the fact that leadership styles employed by school heads have the impact on students, academic performance whether positively or negatively. The problem of leadership is seen as a major challenge in schools. School leadership is considered very significant and many people are capable to be leaders if nurtured appropriately.

Pashiardis and Brauckmann (2009, p.121-122) conducted a study on professional development needs found that leadership plays a crucial role in improving students' achievement. Parshiardis added that academic achievement has lead to an increase in expectations of the role and the growing recognition that the professional development of school leaders could improve their practices.

Another related study by Rautiola (2009) in the study on effects of leadership styles and secondary schools found that, in America, schools focus much on the effectiveness of the classroom and of the school at large. Majority of school heads in America employ participatory leadership style which involves stakeholders including teachers, principles, and parents to play roles in an organisational structure, curriculum, and instruction process.

According to Ozuruoke, Ordu, \& Abdulkarim(2011) contended that in Nigeria, certain aims and objectives to facilitate educational development were being set by the National Policy of Education in the country. In these objectives, heads of school had important roles to perform to make sure that there was success in realization of visions and missions. Among other roles, head teachers were to give effective leadership in secondary schools to ensure that teachers are implemented their performance requirements and set targets. It seems however that many such principals have not considered their styles of administration as the determinant of students' academic performance in the state

In line with this, Huber $(2010$, p.25) in the study on strategies applied by board of management to enhance students' concluded that, in Kenya, majority of school leaders lack competence due to the lack of leadership skills.
Huber added that, there is a broad international agreement that school leaders need the capacity to improve teaching, learning, and pupils' development and achievement. That is to say, school leaders have to be given developmental courses so that they become capable to lead schools towards the achievement of predetermined goals.

In Tanzania, majority of school activities are being organized democratically whereby teachers and school heads work collectively in matters related to discipline and analysis of examination results. Teachers usually meet in staff meetings, and decisions reached in such meetings are sent to school boards for consideration and appropriate actions. The dominancy of a single leadership style may affect negatively or positively the students' academic performance. According to MOEVT (2010 p.13). The school management has been improved by training heads of schools and their assistants on running of schools through capacity offered from time to time by the Agency for Development of Education Management(ADEM)". The ministry further noted that in spite of the relevance of the capacity building programme, very few school heads had an access to this. MOEVT (2010) adds that as such, weak leadership persists among heads of schools as well as teachers leading to poor management skills and supervision of learning programmes and activities especially in secondary schools in Tanzania. The unavoidable result is poor performance. It was further noted that the mass failure of students in secondary schools in Tanzania was the direct reflection of incompetent school leaders, teachers' low morale and performance is an index of a combined failure of the heads of schools in (Ndimbo, 2013; as cited in Jengo, 2016, p.1). This was evidenced from the NECTA examination results of Nyamagana District public schools' results that there is deterioration in academic performance for the past consecutive three years. It is in this regard this study intended to find out the influence of school heads' leadership styles on students' academic performance in public secondary schools, in Nyamagana District in Tanzania.

\section{STATEMENT OF THE PROBLEM}

Public secondary schools in Tanzania in general and in Nyamagana in particular, have been performing poorly for a long time. It is observed that in Nyamagana District, this problem has manifested for a long time. From the National Examination Council of Tanzania examinations results in public secondary schools in Nyamagana District indicate that performance in secondary schools is low. In many cases, 
school heads are being assumed to be the main factor contributing to the outcome of the teaching and learning process. Nevertheless, evidence from records and experience have shown that leadership styles have a positive correlation with the overall school effectiveness because both students and teachers are to perform under school leadership (Florence, 2012). NECTA examination results of 2017 shows that the results percentage of students who scored division one to three were 36.87 percent while those who scored division four and zero were 63.13 percent whereby the total number of students who sat for the examination were 6347; in NECTA examination of 2018 shows that, the pass percentage of students who scored division one to three were 23.73 percent while those who scored division four and zero was 67.27 percent whereby; the total number of students who sat for the examination was 4282 and NECTA examination of 2019 shows that, the pass percentage of students who scored division 1-III was 29.15 percent while those who scored division four and zero were 70.85 percent whereby; the total number of students who sat for the examination was 5232 (Documentation from the DEOs' office, Nyamagana district). It is in this regard, this study intended to investigate the influence of school heads' leadership styles on students' academic performance in public secondary schools in Nyamagana District. The study was interested in investigating the four common leadership styles used by school heads in public secondary schools in Nyamagana District namely laissez-faire, democratic, autocratic, and transformational leadership styles.

\section{PURPOSE OF THE STUDY}

The study was specifically guided by the following objectives;

(i) To determine the influence of laissez-faire leadership style influences students' academic performance in public secondary schools in Nyamagana District.

(ii) To find out the influence of democratic leadership style influences students' academic performance in public secondary schools in Nyamagana District.

\section{SIGNIFICANCE OF THE STUDY}

This study provides knowledge to different educational stakeholders including policymakers, the government, through the Ministry of Education, heads of secondary schools, and future researchers.

The study is important to policymakers since it may inform them on the problems that face public secondary schools so that they can make educational policies that suit the needs of educational schools such as in matters of overcrowding of students in classes, teaching methods, investing in school infrastructure and teacher pay.

On the Governments' side, to be very keen in deploying school managers by making sure that they have undergone management courses, and if not, the government to be sure that all school managers who are in the system and yet they are not qualified should be provided with the in-service courses on management.

The study may contribute in creating awareness among heads of schools on key aspects of leadership styles which might be affecting the academic performance of their schools.

The study also may contribute to improvement of the relationship between teachers and their managers as teachers being satisfied by their ideas being included in managerial activities.

For future researchers, this study may be the addition to their references and literature on leadership and academic performance. That is to say, it may help them to understand the extent to which leadership styles influence academic performance in Tanzania especially in public secondary schools in Nyamagana District as well as in other places worldwide.

\section{LITERATURE REVIEW}

This part discusses the empirical literature review and theoretical literature review as related to the study. Both literature reviews focus on the leadership styles commonly practiced by school heads and their influence on students' academic performance. The theoretical literature review entails the description of the theory and its relevance to the study while the empirical literature review entails the previous studies done relating to this study.

\section{Theoretical Literature review}

\section{Contingent Theory}

Leadership theories are very significant because they explain how behaviour and styles of leadership development. Most of researches on leadership has shifted 
from trait or personality-based theories to situation-based theories which states that the situation in which leadership is practiced is based on characteristics and skills of the leader (Avolio, Walumbwa \& Webber, 2009). This study adopted the contingency leadership theory propounded by Fielder (1978). According to this theory, there is no single leadership style that is adequate to be used in all situations. The success of an organisation depends on some factors being situational features, followers' qualities, as well as leadership style, practiced (Charry, 2012; as cited in Amanchukwu et. al., 2015 p. 8). The contingency theory states that "effective leadership depends on a degree of fit between a leader's qualities and leadership style and that demanded by a specific situation" (Lamb, 2013). That is to say, leadership styles depend upon many variables. The theory emphasizes that leadership styles are crucial for all organisations. A school head should adopt a variety of leadership styles and apply them according to the need or situation

\section{Empirical Literature review}

This section review different kinds of literatures related to the two types of leadership styles commonly used by school heads in Nyamagana District and their influence on students' academic performance as revealed by different scholars globally, regionally as well as locally in Tanzania. The study considers the two leadership styles which are laissez-faire and democratic leadership styles, and how they impact students' academic performance.

\subsection{Laissez-faire Leadership Style and Students' Academic Performance}

In this type of leadership style, the school heads leave the teachers to be free to do what is worth to them without any directives or reminders. The school heads believe that teachers are mature and they have knowledge and skills hence they can lead themselves as individuals. School heads and subordinates under laissez-faire are free to do whatever they like. (Achimugu and Obaka , 2019; Okumbe ,1998; as cited in Igwe, Ndediamka and Chidi, 2017). These scholars further posit that in the laissez-faire leadership style, the leader is reluctant. That is to say, the leader does not have any control of subordinates since authors consider the laissez-faire- leadership style as the absence of leadership. In this study, laissez-faire leadership means leaving subordinates to do whatever they see is right but under the guidance of the leader making sure that the organisational goals are fulfilled.
The study conducted by Nguyeni and Glover (2017) on Laissez-faire leadership behaviours in the public sector in Vietnam found that Laissez fair leadership had a negative influence on the psychological safety climate of organizations and increased bullying behaviours at work settings. Also, they found that laissez-faire leadership practice is positively associated with psychological wellbeing among employees, which was negatively related to workplace bullying. Lack of an effective regime for monitoring of regulations governing principals' behaviour and the characteristics of the bullies and victims are reasons for bullying. According to De Wet (2010), victims of bullying at school are teachers. Laissez-faire leadership style is assumed to be a destructive leadership style due to it being a workplace stressor, especially through exposure to bullying.

The study conducted by Ekmekci \&Tosunoglu (2016) looked at laissez-faire leaders and organizations. They found that the experience of laissez-faire leadership by the leader was strongly related to the reduced level of trust by the subordinates and the organization at large. Ekmekci \& Tosunogu added that laissez-faire is one of the ineffective and destructive leadership styles, which was assumed to erode and erode trust both in supervisors as well as organisations. Ekmekci \& Tosunogu continue to argue that laissez-faire leadership style results in psychological bleach whereby employees perceive their supervisors as reluctant or incompetent to satisfy their needs and they seem to lose their confidence in their organisation, which is losing trust in the organisation as time passes. Judeh $(2016$, p.2) asserts that people who have trust in their organisation believe that management has good intentions and thinks positively of all behaviours and decisions issued by management. One of the managers' roles in this regard is to create a climate of trust in an organisation. This will in turn improve teachers' attitudes to work hence better students' academic performance.

Boke, Nyakundi \& Nyamwoka (2017) studied leadership styles used by principals in the performance of secondary schools in Kuria- West Sub - County, Kenya. Boke, et al. revealed that the laissez-faire leadership style was being used in many schools. Where the heads of schools applied laissezfaire leadership style, the mean standard score for schools was relatively low. They added that the type of leadership style employed by the head of schools could be one of the factors which lead to the poor academic performance of students. Also using a laissez-faire leadership style could result in a lack of teachers as well as students' discipline due 
to non-enforcement of rules and regulations in a school leading to poor performance in examinations. Nthakyo, Mungai, \&Malela (2016) argue that school heads should adopt leadership skills and mechanisms which are aimed at instilling discipline in students as well as teachers. Schools should organize workshops and seminars, especially for students' leaders so that they acquire skills for discipline to be applied to their fellow students at school. Also, schools should acquire a collaborative approach with stakeholders which in turn will help in addressing students' indiscipline at school.

Isundwa (2015) looked at the influence of leadership styles on students' academic performances in secondary schools in Morogoro municipality, Tanzania. The study found that there is a very negative influence of laissez-faire leadership style on students' achievement. Also, laissez-faire leader does not bother to tell subordinates their wrongs or weaknesses as they leave all tasks to them done independently leading to poor students' academic achievement. Wu \& Shiu (2009) observes that laissez-faire is not a good leadership style to be used by school heads because complete delegation without follow-up creates performance problems. $\mathrm{Wu} \&$ Shiu added that teachers and students are motivated when they are afforded opportunities to make their own decisions. The acceptance of their opinions and ideas combined with the performance monitoring done by school heads is a healthy way of enhancing discipline and better students' academic achievement of a school organization.

From the literature previously cited, it is not advisable for school heads to practice laissez-faire leadership style because its attributes such as bullies, extreme delegation, and employee loss of trust in organisations as well as indiscipline of teachers and students lead to lack of teacher satisfaction and eventual poor work performance and poorer students' academic performance. Literatures reviewed have not explained the good-side of using the laissez-faire leadership style although there are situations which may allow its use in schools. Laissez-faire can be used in effective situations where subordinates are highly skilled, capable of working on their own, and motivated. The justification here is that, in this situation, all members are experts, have skills and knowledge to work independently with very little follow-up or guidance from the leader.

\subsection{Democratic Leadership Style and Students' Academic Performance}

This kind of leadership is collegial and every member of a group is allowed to participate in the process of decision making (Ukaidi, 2016). Mullins, (2005) contends that democratic leadership style is the style in which the focus of power is within a group and there is greater interaction within that group and a leader is more part of the group. The leadership tasks are shared by group members. Members have a greater say in matters of decision making, determination of policy, and implementation of the policy (p. 317). These definitions agree that the democratic leadership style is collective.

Because of discrepancies in the definitions above, this study is going to base on the definition stating that, democratic leadership style is the leadership style in which the leader includes one or more subordinates in the decision-making process in the organisation while the leader retains the final say in these decisions as contended by Obama, Eunice, and Orodho (2015). In this case, the leader is the one who makes the final decision basing on decisions from subordinates' views. For the case of the school environment, this style is practiced by having collective participation in decision making among stakeholders of the school. This leadership style works well for the organisation where all members are well skilled and they are competent in doing things on their own. Whereas the studies above explain the relationship between democratic leadership style and subordinates' performance, they do not show the relationship between leadership style and students' academic performance. This study addresses that gap showing how $\mathrm{d}$ comes into conclusion. Also, in the democratic leadership style, the head of schools motivates teachers either materially or by praising them whenever they seem to perform well in their tasks.

Sultan (2017) in the study on leadership styles executed by principals and academic coordinator in school in Gilgitistan, Pakistan found that democratic leadership style dominated in many of the schools in which heads of schools and academic masters always involved the subordinates, the head assistants, and other stakeholders in the process of making decisions. This democratic leadership approach was used to facilitate learning processes in the school, though this style varied under different circumstances. Sultan added that in schools, heads use the principles of democratic leadership to decide 
about the tasks to be accomplished to make their institutions effective. Sultan adds that because the subordinates were involved in the decision-making process they seemed to have a sense of belongings towards tasks.

On their part, Kavale \& Omar (2015), reported that most of the heads of secondary schools had already adopted the democratic leadership style and the students and staff performed better than in schools where the heads practised other styles of leadership. The practice of democratic leadership involved inviting contributions from the subordinates before making decisions. The leaders allow subordinates to vote over a presented issue and, thereafter, the decisions are made. School heads coach subordinates and negotiates their demand. They added that leaders of schools should use the most appropriate leadership style to facilitate collective responsibility and consultative decision making by all educational stakeholders.

Consequently, the study conducted in South Africa by Mncube \& Potokri (2015) on leadership roles of school heads in democratic schools found that the principals at the South African democratic schools practiced democratic principles to develop a democratic culture in their schools as well as to improve students' academic achievement. Teachers, learners, heads of schools, and students seem to be happy about the democratic leadership style practiced in their schools. Mnicube and Potokri suggest that more can be done through the inclusion of stakeholders in major decision making processes at school. This gives every person in school a genuine sense of belonging and ownership of the school. As a result, morale and the team spirit are stimulated for better performance and higher productivity. Without an organizational democratic culture, with educational morals, organizational knowledge cannot be created. Thus without organizational knowledge there is no innovation, and without innovation, there is no development, and without development, there is no competitiveness which is extremely vital for contemporary world economies in this globalized society (Marcopoulos \& Vanharanta, 2014, p.12). In the school context, democratic culture is very crucial for the job satisfaction of subordinates which leads to the better and competitive academic performance of students in final examinations.

Kosgei, Tanui \& Rono, (2018) investigated the influence of selected leadership styles of principals on the performance of public secondary in Narok South, Kenya. They found that the democratic leadership style is the preferred type and is used by many school heads. The

ISSN: 2456-7620

https://dx.doi.org/10.22161/ijels.56.71 democratic style is considered to have a greater influence on the performance of students in National examinations. At schools, the head of schools involve subordinates in the preparation of the school budget, and always school heads consult teachers on matters of procurement and school spending on teaching and learning materials and other resources.

The study conducted by Aunga \& Masare (2017) on the effect of leadership styles on teachers' performance in Arusha District in Tanzania found that as the democratic leadership increases in a school, the performance of teachers become greater which leads to high students' academic performance. The scholars further asserts that the more democratic leadership increases, the more teachers' performance increases which imply that democratic leadership affects teachers' performance positively. This in turn leads to students' high academic performance. According to Abwalla (2014), school heads' leadership styles in secondary schools have a significant effect on decision making, delegation, and communication to improve the level of teachers' job performance. While teachers' ideas and taught should be considered in decision-making to enhance their performance.

According to previous authors, the democratic leadership style if properly practiced by school heads by the consideration of varied circumstances it might lead to better students' academic performance or otherwise. When properly practiced, teachers, students, and other stakeholders become motivated and this develops in them the sense of belongingness to the school organization which leads them into better involvement in the teaching and learning process hence, better students' academic performance. All in all, in order to democratic leadership style to be successful, it should be used along with other leadership styles since situations at school do vary time after time. In a school environment, especially in the Tanzania context, the democratic leadership style is practiced by school heads mainly by conducting staff meetings frequently where school heads and other staff members share ideas on the issues raised.

\section{METHODOLOGY}

This study employed Mixed Methods Research approach. Mixed research methods involve the collection and integration of both quantitative and qualitative data in a study (Cresswell, 2014). The researcher chose this method 
because it provides strengths that offset the weakness of both qualitative and quantitative research. The importance of using a mixed research design is that it helped us in obtaining information originating from the experience of participants themselves.

The study employed convergent parallel design. Convergent parallel design entails that a researcher concurrently conducts the quantitative and qualitative elements in the same phase of the research process, weighs the methods equality, analyzes the two components independently, and interpret the results together (Cresswell and Pablo-Clark, 2011). Therefore in a convergent parallel method, a researcher went to the field once, collected data concurrently or simultaneously, analyzed data separately and merged it at the end of the study.

The target population was 30 heads of schools, 1195 teachers, and 30 academic teachers from public secondary schools as well as 1 District Educational officer of Mwanza City Council in Nyamagana District, Mwanza Region who made the total population of 1259 individuals. The study targeted all secondary school teachers, school heads, and District Educational Officer because they were responsible in the process of teaching and learning in secondary schools also they play the role of leadership in influencing students' academic performance.

Both probability and non- probability sampling techniques were employed to get the sample size of the study. The total sample size of the study was 111 participants where 100 were teachers, 5 school heads, 5 academic teachers and 1 District Educational Officer. The researcher used simple random technique in getting 5 schools.

This study employed questionnaires to collect data from teachers; in-depth interview guide to collect data from the DEO, school heads, academic teachers, observation, as well as document review in collecting the required data.

The accuracy and consistency of research instruments of this study were measured by the use of validity and reliability. Validity refers to what an instrument measures and how perfect and good it measures. It is the truthfulness of the findings (Mohajan, 2017; Altheide \& Johnson, 1994). The validity of an instrument in this study was measured through content and face validity. In order to check on content validity, the researcher gave the questionnaire and interview guide to reviewers who had knowledge of the research instruments. These included two postgraduate research supervisors at Saint Augustine University, Mwanza Main

ISSN : 2456-7620

https://dx.doi.org/10.22161/ijels.56.71
Campus who checked the relationship between the research instruments' items and the real situation in the area of the study. Then, these supervisors critiqued the instruments and gave advice on what to omit and what to add for the sake of the validity of instruments. Reliability refers to when a measurement brings consistent results with equal values. The instrument measures the consistency, truthfulness, precision, and repeatability of research (Blumberg, Cooper \& Schindler, 2005; Chakrabartty, 2013). Testing reliability in this study was important because it is the assurance of the accurate results of the study. In this study, reliability was measured by the split-half reliability method. In this study, 20 participants were involved in the test. The researcher scored two halves that are odd and even items of the test separately for category of instruments. Then, the calculation of the correlation co-efficiency of the two sets of scores was done. The coefficient shows the degree to which the two halves of the test provide the same results and therefore describes the consistency of the test. The researcher used Spearman Prophecy Formula in testing the reliability of the instruments:

This study utilized a note book for recording data obtained qualitatively. This was during the interviews with the DEO, school heads, and school academic masters. The same was used to record information on students' academic performance from records on national examination.

This study was mixed research in which quantitative data were analysed using the Statistical Package for Social Sciences (SPSS) Version 21.0. Data from closed items in questionnaires were analysed using descriptive statistics and were presented in frequencies, percentages, tables, and charts. Qualitative data obtained from open-ended questionnaires and in-depth interviews and which cannot be coded with SPSS were summarized using open coding to get categories and themes.

\section{RESULTS AND DISCUSSION}

The presentation, discussion, and interpretation of research findings were presented on the basis of the research objectives.

\section{Laissez - faire leadership style and Students' Academic Performance}

This section intended to explore whether school heads in Nyamagana District public secondary schools employ laissez- faire leadership style. The information was gathered by using laissez- faire leadership style characteristics 
International Journal of English Literature and Social Sciences, 5(6)

Nov-Dec 2020 / Available online: https://ijels.com/

manifested by school heads. The results were as shown in

table 4.1

Table 4.1:

Teachers' Response on Laissez-Faire Leadership Styles' Characteristics

\begin{tabular}{|c|c|c|c|c|c|c|c|c|c|c|c|}
\hline \multirow[t]{2}{*}{ Characteristics } & \multicolumn{2}{|c|}{ SD } & \multicolumn{2}{|r|}{ D } & \multicolumn{2}{|c|}{$\mathbf{U}$} & \multicolumn{2}{|c|}{$\mathbf{A}$} & \multicolumn{2}{|c|}{ SA } & \multirow[t]{2}{*}{$\mathbf{n}$} \\
\hline & $\mathbf{F}$ & $\%$ & $\mathbf{F}$ & $\%$ & $\mathbf{F}$ & $\%$ & $\mathbf{F}$ & $\%$ & $\mathbf{F}$ & $\%$ & \\
\hline Fail to take necessary actions & 7 & 7.0 & 38 & 38.0 & 12 & 12.0 & 11 & 11.0 & 32 & 32.0 & 100 \\
\hline $\begin{array}{l}\text { Leave decisions to be made by } \\
\text { teachers }\end{array}$ & 32 & 32.0 & 26 & 26.0 & 6 & 6.0 & 25 & 25.0 & 11 & 11.0 & 100 \\
\hline $\begin{array}{l}\text { Subordinates solve their own } \\
\text { problems alone }\end{array}$ & 21 & 21.0 & 19 & 19.0 & 20 & 20.0 & 25 & 25.0 & 16 & 16.0 & 100 \\
\hline $\begin{array}{l}\text { Does not interfere decisions } \\
\text { made by subordinates }\end{array}$ & 20 & 20.0 & 22 & 22.0 & 12 & 12.0 & 26 & 26.0 & 20 & 20.0 & 100 \\
\hline Delegate power to subordinates & & 20.0 & 27 & 27.0 & 11 & 11.0 & 31 & 31.0 & 11 & 11.0 & 100 \\
\hline
\end{tabular}

Source: Field data (2020)

Table 4.1 indicates that teachers who agreed that school heads fail to take necessary actions were 47 percent while those who disagreed were 45 percent. Those who disagreed on school head leave decisions to be made by subordinate were 58 percent while those who agreed were 36 percent. On the statement that subordinates solve their own problems alone 40 percent disagreed while 41 percent agreed. 42 percent disagreed and 46 percent agreed on the statement that school heads do not interfere decisions made by subordinates and 46 percent disagreed while 42 percent agreed on school heads delegate power to subordinates. Hence the ratio of teachers who disagreed and who agreed on the statements were almost equal.

This study revealed that many school heads make necessary actions whenever the situation at hand allows them to do so. In some schools, school heads may decide to leave decision to be made by subordinates mainly because they found that their subordinates are more knowledgeable than them. Isundwa (2015) to whom in his study found that there is a very low influence of laissez-faire leadership style on students' achievement since laissez-faire leader does not bother to tell subordinates their wrongs or weaknesses as they leave all tasks to them done independently.

In laissez-faire type of leadership, delegation of power is a dominant characteristic feature. The study found that, School heads delegate power to subordinates because they want to develop knowledge and skills of teachers instead of being stagnant. Therefore, the bad side of laissez-faire leadership style overpowers the good side hence the lack of guidance of school heads to teachers leads to poor performance of students in National examinations. This is supported by Isundwa (2015) who supports this statement by stating that, the delegate in laissez-faire is very high. This leads to poor students' academic achievement. Wu \& Shiu (2009), laissezfaire is not a good leadership style to be used by school heads because complete delegation without follow-up creates performance problems.

Leaving decisions to be made by subordinates on their own is one of the characteristic of laissez- faire leadership style. Wu \& Shiu add that teachers are motivated when they are afforded opportunities to make their own decisions. The acceptance of their opinions and ideas combined with the performance monitoring done by school heads is a healthy way of enhancing discipline and better students' academic achievement of a school organization. The study found that, school heads in Nyamagana District does rarely allow subordinates to make their own decisions. This may be the reason to why students of public secondary schools perform poorly in National examinations.

The results in this study indicate that, in Nyamagana public secondary schools, laissez -faire leadership style is practiced in large extent. It is very important to not apply laissez- faire leadership style in totally because it may lead to poor performance of students. This statement was supported by 
Achimugu and Obaka (2019) who contended that, institutions where laissez-faire leadership is practiced, it is feared that teachers and students may become lazy of fulfilling their responsibilities, and this will affect teaching and learning and will in turn affect student achievement negatively. Therefore, laissez-faire leadership can be considered as an "absence of leadership" since every individual in an organization does what is good or right according to him or her without any directive.

Boke, Nyakundi \& Namoki (2017) in a related study add that where the head of schools applied a laissez-faire leadership style, academic performance of students become relatively low. They added that the type of leadership style employed by the head of schools could be one of the factors which lead to the poor academic performance of students. Also using a laissez-faire leadership style could result in a lack of teachers as well as students' discipline due to non-enforcement of rules and regulations in a school leading to poor performance in examinations.

Key: $1=$ Strongly disagree, $2=$ Disagree, $3=$ Undecided, 4=Strongly agree, $4=$ Agree, $F=$ Frequency, $\%=$ Percentage

Findings from qualitative where open-ended questionnaires were provided to teachers and in-depth interviews were provided to school heads, academic teachers and the DEO hence the detailed information on laissez fair leadership style was obtained.

\section{Lack of confidence in doing things}

From the open- ended question provided in teachers' questionnaire, Majority of teachers responded to the reason to why their school heads employ laissez- faire leadership style because they lack confidence in doing things. One of the teachers in school 3 stated that;

The headmaster in our school in our school delegates power extremely. He delegates even the responsibilities which can be done by him. This shows that he is not confident on his responsibilities (July, 2020).

Meanwhile another teacher from school number 2 revealed that;

Our school head delegates responsibilities to the school management team but she does not always make the follow up on the feedback of the responsibilities provided to the delegates. If it happens that the delegates accidentally provide feedback, she does not provide any challenge (July, 2020).

\section{Leadership knowledge}

From the open- ended question provided in teachers' questionnaire, Majority of teachers responded to the reason to why their school heads employ laissez- faire leadership style because they have little or no leadership knowledge. One of the teachers in school 1 stated that;

Our school head is a degree holder. I think that is why he uses laissez-faire leadership style. If he could have undergone leadership courses, I am sure that he could be able to use different leadership style whenever the situation needs him to do so. In our school you find teachers doing whatever they see it is right to them. For example, a teacher may decide to dodge his or her classes and the headmaster do not take any measure on them (July, 2020).

The findings are in line with the Nthakyo, Mungai, \&Malela (2016) who contended that school heads should adopt leadership skills and mechanisms which are aimed at instilling discipline in students as well as teachers. Schools should organize workshops and seminars, especially for students' leaders so that they acquire skills for discipline to be applied to their fellow students at school. Also, schools should acquire a collaborative approach with stakeholders which in turn will help in addressing students' indiscipline at school.

\section{Teacher's job satisfaction}

From the in-depth interviews with school heads, academic teachers and the DEO the researcher obtained the detailed information on laissez- faire leadership style that, majority of respondents stated that laissez-faire leadership style enhances teachers' job morale. The school head of school number 4 argued that;

There are situations in school where laissez- faire leadership style should be applied. I believe that, there are some areas where I can notice that, some subordinates are more knowledgeable than me but I cannot expose it to them rather than giving them a chance to practice their talents. In turn this make them satisfied with their job which then enhances academic performance of students (July, 2020).

Furthermore, the academic teacher from school number 5 added that; 
Laissez-faire leadership style is very important to be used in Nyamagana secondary schools because it arise the morale of teachers and teachers feel that they are identified and their potentials are respected. This leads to good students' academic performance because teachers will be working very hard, completing syllabuses, making revisions only to attain school pre-determined goals (July,2020).

\section{Democratic Leadership Style and Students' Academic Performance}

In this section, the researcher intended to explore if school heads in Nyamagana District public secondary schools employ democratic leadership style. The information gathered were the laissez- faire leadership style characteristics manifested by school heads and the reasons to why the mentioned leadership style was applied. The information was gathered by using democratic leadership style characteristics manifested by school heads as shown in table 4.2

Table 4.2:

Teachers' Response on Democratic Leadership Styles' Characteristics

\begin{tabular}{|c|c|c|c|c|c|c|c|c|c|c|c|}
\hline \multirow[t]{2}{*}{ Characteristics } & \multicolumn{2}{|c|}{ SD } & \multicolumn{2}{|c|}{ D } & \multicolumn{2}{|l|}{$\mathbf{U}$} & \multicolumn{2}{|l|}{$\mathbf{A}$} & \multicolumn{2}{|l|}{ SA } & \multirow[b]{2}{*}{$\underline{\mathbf{n}}$} \\
\hline & $\mathbf{F}$ & $\%$ & $\mathbf{F}$ & $\%$ & $\mathbf{F}$ & $\%$ & $\mathbf{F}$ & $\%$ & $\mathbf{F}$ & $\%$ & \\
\hline $\begin{array}{l}\text { Solves administrative problems } \\
\text { with subordinates }\end{array}$ & 35 & 35.0 & 9 & 9.0 & 7 & 7.0 & 47 & 47.0 & 2.0 & 2.0 & 100 \\
\hline Shares leadership role & 21 & 21 & 21 & 21 & 14 & 14 & 28 & 28 & 18 & 18 & 100 \\
\hline With subordinates & & & & & & & & & & & \\
\hline Treats all members equally & 27 & 27 & 26 & 26 & 9 & 9 & 27 & 27 & 12 & 12 & 100 \\
\hline $\begin{array}{l}\text { Respect teachers' opinions in } \\
\text { Decision making }\end{array}$ & 30 & 30 & 10 & 10 & 7 & 7 & 46 & 46 & 7 & 7 & 100 \\
\hline
\end{tabular}

Source: Researcher, 2020

Teachers' response in table 4.2 shows that, the percentage of teachers who disagreed and those who agreed on the statements on democratic leadership style were almost equal. The percentages of who disagreed on if their school heads solves administrative problems with subordinates were 44 percent, share leadership roles with subordinates formed 42 percent, treat all members equally formed 53 percent, and respects teachers' opinions in decision making were 40 percent. The percentages of teachers who agreed on if their school heads solves administrative problems with subordinates were 49 percent, share leadership roles with subordinates formed 36 percent, treat all members equally formed 39 percent, and respects teachers' opinions in decision making were 53 percent. The results imply that, democratic leadership style is practiced in some extent by school heads in public secondary schools in Nyamagana District.
The tendency of solving administrative problems is very crucial in an organization. It is very important for school heads to involve subordinates in solving non emergency administrative problems which do not require urgent solution. By respecting the ideas of subordinates this will make them feel that they are belonging to an organization hence improving their morale to work which then leads to good students' academic performance. Supporting this study, Kavale \& Omar (2015) contend that the practice of democratic leadership style is by inviting contributions from as many stakeholders as possible before making decisions. The leaders allow subordinates to vote over a presented issue and, thereafter, the decisions are made. School heads allow subordinates to negotiate their demands from the institution. They added that leaders of schools should use the democratic leadership style to facilitate collective responsibility and consultative decision making with subordinates. 
Sharing leadership roles with subordinates is very important at schools because it is believed that everyone is talented in one way or the other. There are some subordinates who are knowledgeable in some areas where the school head has no knowledge on them. This is very important in that it helps the school as an organization to move forward towards the attainment of its pre-determined goals.

Treating all members equally in the school is also very important. This removes the sense of inferiority complex to the once who might be segregated and are able to perform their tasks well. School heads in public secondary schools should avoid segregation among subordinates which could make those segregated subordinates to lose morale for work which might lead to poor students' academic performance.

School heads should respect the opinions from subordinates which should be considered in arriving at the final say in terms of conclusion. By doing this, teachers will be satisfied in their job hence performing their tasks well. This implies that democratic leadership style, if is applied in school organization, motivates teachers in doing their work well which results in good students' academic performance.

Kavale \& Omar (2015) added the same idea that school heads of secondary schools who had already adopted the democratic leadership style, students and staff perform better than of other schools where the school heads are practicing other types of leadership style. The practice of democratic leadership style was by inviting contributions from the subordinates before making decisions. The leaders allow subordinates to vote over a presented issue, thereafter the decisions are made. School heads coach subordinates and negotiates their demand. They added that leaders of schools should use the most appropriate leadership style to facilitate collective responsibility and consultative decision making of all educational stakeholders, the collective leadership style being the democratic leadership.

Key: $1=$ Strongly disagree, $2=$ Disagree, $3=$ Undecided, 4=Strongly agree, 4= Agree, $F=$ Frequency, $\%=$ Percentage

Findings from qualitative where open-ended questionnaires were provided to teachers and in-depth interviews were provided to school heads, academic teachers and the DEO hence the detailed information on democratic leadership style was obtained.

\section{Decision making}

Majority of teachers in questionnaires responded on that their school heads applies democratic leadership style. They ISSN: 2456-7620 revealed that their school heads involves them in decision making process hence they are satisfied with their work by feeling that they are recognized as a part of the organization.

In line with this, the interview with the academic master from school number 1 stated that;

between teachers and our school head. Not only that, also every teacher develops the spirit of working effectively without being forced. This fosters the improvement of academic performance in our school (July, 2020).

Another academic teacher from school number 3 added that;

Our school head employs democratic leadership style because it provides perfect supervision by for example, controlling teaching schedule, making sure that teachers provide exercises, ensuring punctuality of teachers Our school head employs democratic leadership style because it provides perfect supervision by for example, controlling teaching schedule, making sure that teachers provide exercises, ensuring punctuality of teachers and students as well as their discipline. This helps in the improvement of students' academic performance. Also, democratic leadership style gives an access to the management in getting some information on teaching and learning process so that the problems revealed can be solved easily (July, 2020).

Another academic teacher from school 5 added that;

Our school head motivates us in many ways for example; he sometimes provides lunch to teachers and during form four graduations, he use to provide letters of appreciation or money as gifts to those teachers to Our school head motivates us in many ways for example; he sometimes provides lunch to teachers and during form four graduations, he use to provide letters of appreciation or money as gifts to those teachers to whom their students did well in the subjects they use to teach. Not only that, also our leader cares for us whenever we face different challenges including family once. (July, 2020). 
The DEO during the interview mentioned democratic leadership style as one of leadership styles employed by school heads in his district. He pointed out that;

School heads use democratic leadership style in that; they use to give chances to teachers to provide some explanations with reasoning whenever it is required before taking further disciplinary action. To ensure that teaching and learning process goes well, school heads use to assess it and after that, reports are given out to teachers where leaders discuss with teachers on issues concern with teaching and learning process then they rich into conclusion (August, 2020).

These findings are in line with the study conducted by Musa (2014) which contended that the school level motivation is an important aspect which can improve school performance. Teachers' participation in decision- making leads to the recognition of intellect power and when teachers, intellect power is acknowledged, they participate more, become creative and satisfied. Therefore, school heads should respect teachers' ingenuity, knowledge, and growth, ideas, decision making, maintain friendship, and collegiality.

During the study, the researcher observed that teachers, there are frequent staff meetings where by teachers and school heads do sit and discuss on issues concern the school organization. This was evidenced by staff meeting minute book which was deliberately requested by the researcher and through oral interaction with teachers. Mullins, (2005) contends that democratic leadership style is the style in which the focus of managing power comes from subordinates and there is greater interaction within that group whereby a leader is a part of the group. The leadership duties are shared by group members. All group members are given a chance to participate in decision making process, determination of policy, and implementation of the policy (p. 317).

The objective number two agrees with the Contingency leadership theory in that, it is necessary to apply it in school organization but its downside comes when it is applied alone as well as extremely without incorporating other leadership styles. The theory admits that all leadership styles are productive only if leaders use them in combination.

The findings from these interviews and observation indicate that, in Nyamagana District public secondary schools, there is the application of democratic leadership style in some extent by involving subordinates in decision making process. By doing that teachers develop the spirit of hardwork. They realize that they are able and that the organization belongs to them. Hence, there is improvement of students' academic performance. However, democratic leadership style when used without caution leads to poor academic performance. Therefore, democratic leadership style is very important in an organization because if applied effectively, it helps in making teachers commit themselves to work by teaching effectively. Also, through democratic leadership teachers inspire students to be committed to their studies by searching their materials on their own for knowledge deepening. This brings good academic performance in national examinations.

\section{CONCLUSIONS AND RECOMMENDATIONS}

This sub-section presents the conclusions from the study findings as follows hereunder;

The study discovered that, school heads in public secondary schools, except very few of them employ a single leadership style among laissez- faire and democratic leadership styles of which is not adequate to elicit positive attitude to work in case of teachers and the attitude of students towards studying hard to achieve higher grades in their final examinations. The study discovered that, very few school head apply a mix of leadership style. It was revealed that, in those schools, the performance of students is good compared to other majority of schools.

On laissez- faire leadership style, the study concluded that school heads were not able to elicit good results due to over delegation of responsibilities without follow up. This in turn causes the drop of students' academic performance. However, laissez- faire leadership style should be used in some extent while mixing with other leadership styles.

The study revealed that, even if when used together with other leadership styles, democratic leadership style is the type of leadership style which when used effectively results into good academic performance of students. The study concluded that, when democratic style is employed, teachers become satisfied because when they are involved in decision making, they feel as a part of an organization.

Moreover, the study concluded that school heads should employ a mix of leadership styles so that to elicit high students' academic performance. It is necessary to use a mix of leadership styles because each of them has the 
strength which covers weakness of others. This can lead to high students' academic performance.

\section{Recommendations}

Based on the findings, summary and conclusion, the following recommendations were made:

(i) The government through its organs which are the ministry of education and the President's Office, Regional Administration and local Government Office (PO- RALG) should make sure that it appoint school heads that have already under gone leadership training courses so that they could be competent leaders at school levels.

(ii) The government through its organs which are the ministry of education and the President's Office, Regional Administration and local Government Office (PO- RALG) should make sure that, those school heads who have already been appointed as school heads and who have not under gone any leadership course are provided with professional development programs, workshops as well as seminars in order to equip them with knowledge and keep them updated with the trending new leadership skills.

(iii) For school heads who already have leadership skills are supposed to employ them due to school contextual situation. This would make teachers to perceive their school heads as flexible hence motivated to work harder. This in turn would lead to improvement of academic performance of students in National examination.

\section{REFERENCES}

[1] Abwalla, J. (2014). The principals' leadership styles and teachers' performance in general secondary schools of Gambella in Regional State. Jimma University, Ethiopia. Dissertation

[2] Amanchukwu, R. N., Stanley, G. J. \& Ololube N.P. (2015). Review of leadership theories, principles and styles and their relevance to educational management: Retrieved from www.researchgate.net

[3] Amin, E.M. (2005). Social science research conception, methodology, and analysis: Kampala. Makerere University printers.
[4] Aunga, D.A.O. \& Masare, O.(2017).Effect of leadership styles on teachers' performance in primary schools of Arusha district, Tanzania. International Journal of Education Policy Research and Review, 4(4), 42-52

[5] Avolio, B. J., Walumbw, F. O. \& Weber, T. J.(2009). Leadersip: Current Theories, Research, and future Directions. Journal of Review of Psychology, 60, 421- 449

[6] Boke, C., Nyakundi, E. \&Nyamwaka, E. (2017). The implication of leadership styles used by principals on the performance of secondary Schools in Kuria west sub-county. Kenya Journal of humanities and social science (IOSRJHSS), 22, (2) ver 6, 01-07.

[7] Boyaltis, R. E. (1998). Transforming qualitative information : Thermatic analysis and code development. Thousand Oaks, CA: Sage

[8] Chakrabartty, S. N. (2013). Best split-half and maximum reliability. IOSR Journal of Research methods in Education, 3(1), 1-8.

[9] Cresswell, J.W., Pablo-Clark, V.L.(2011). Designing and conducting mixed methods research $2^{\text {nd }}$ Edition, Sage Publications, Los Angeles.

[10] Creswell, J.W. (2014). Research design qualitative, quantitative and mixed methods approaches Los Angeles London/ new Delhi Singapore/ Washington DC Sage.

[11] De Wet, C. (2020). The reason for and the impact of principal on teacher bullying on the victims private and professional lives. Teaching and teacher professional lives. Journal of teaching and Teacher Education, 26(7), 14501459

[12] Ekmekci,O.T. \& Tosonoglu, H. (2016). Laissez-faire leaders and organizations: how do laissez faire leader erode the trust of an organization. The Journal of Economics, Finance and Accounting, 3(1), 89- 97

[13] Fielder,F. E. (1978). The contingency model and the dynamics ofleadership process. In: L. Berkowitz (Ed.), Advances in experimental social psychology(Vol. 11). New York: Academic

[14] Ganesh T. (2009). Reliability and validity issues in research. Journal of intergration and dissertation research bulletin, 4, 35- 40

[15] Huber, D.L. (2010). Leadership and Nursing case Management: $5^{\text {th }}$ Edition. Retrieved from www.unesco.org.

[16] Igwe, N.N., Ndediamka, M.O. \& Chid, E. F. (2017). Principal Leadership Styles and students' academic performance in Enugu Metropolice. Journal of comparative survey of public and mission secondary schools; achieve of business research, 5(8), 7-30.

[17] Isundwa, S.P. (2015). The influence of leadership styles on secondary student academic achievement in secondary schools in Morogoro municipality, Tanzania (unpublished Masters thesis). The Open University of Tanzania, Morogoro. 
[18] Jengo, L. S. (2016). School management in community secondary schools in Rombo District: Effects on the students' academic performance (unpublished dissertation). The Open University of Tanzania, Dar es salaam.

[19] Judeh, M. (2016). The influence of organizational trust on job performance: Mediating role of employee engagement. International Journal of Business, 16(5), 53-56

[20] Kavale, S. \&Omar, A.M. (2016). Effect of leadership style on school performance of secondary schools in Wadajir District, Mogadishu, Somalia. Journal of Applied Management Science, 2(5)

[21] Kosgei, A.C. Tanui, E. \& Rono, R. (2018). Influence of selected leadership styles of principals on performance of the public secondary schools in Narok South, Kenya. International Journal of Scientific and Education Research, 2(1), 34-49

[22] Kuluchumila, E. C.(2014). Preparation and Development of Secondary School Heads: What should be done in Tanzania? British Journal of Education. Vol, 2(2), 9-39

[23] Kvale, S. (1996) Interview: An Introduction to Qualitative Research Interviewing. Thousands Qak, California: Sage.

[24] Lamb, R. (2013). Howcan managers use participative leadership effectively? Retrieved from www.Task.fm

[25] Markopoulos, E. \& Vanharanta , H. (2014). Democratic culture paradigm for organizational management and leadership strategies: The company democracy model. Retrieved from www.researchgate.net

[26] Mnicube V.S. and Potokri, O.C. (2015). Leadership role of school principals in democratic school in South Africa: Case studies of two schools. Retrived from www.researchgate.net

[27] MOEVT, 2010.Proposed secondary development program (SEDP II), 2010-2014

[28] Mullins , L. J. (2005). Management and organizational behavior; Prentice-Hall.

[29] Nannyonjo, H. (2017). Building capacity of school leaders: Strategic that work. Jamaican experience (English). Washington D.C: World Bank

[30] Nguyeni, D. \& Glover, S.L. (2017). Laissez-faire leadership Behaviour in Public Sector in Vietnam. Retrieved from www.reserachgate.net

[31] Ntakayo, K.G., Mungai, G. A. \& Malela, K.P. (2006). Principals' leadership practices and their influence on students' discipline in public secondary schools in Makindu sub-county, Kenya. Journal of Mechanical and Civil Engineering, 13(5),08-14

[32] Obama, M. O., Eunice, L. A. \& Orodho, J. A. (2015). Effects of principals leadership styles on students Academic performance in public secondary schools in Homa-Bay Country, Kenya. Journal of Humanities social sciences (10SR-JH SS), 20(3), ver. VII, 51-60
[33] Pashiardis, P. \& Brauckmann, S. (2009). Professional development needs. Retrieved from www.academia.edu

[34] Rautiola, J.D. (2009). Effects of leadership styles and secondary schools (Unpublished master's thesis). Northern Michigan University. USA.

[35] Ukaidi, C. U. (2016). The influence of leadership styles on organizational performance in Nigeria. Global Journal of Human Resource Management, 4(4), 25-34

[36] Wu, F. Y. \&Shiu, C.(2009). The relationship between leadership styles and foreign English Teachers job satisfaction in adult cram schools: Evidence in Taiwan. Journal of American Academic Business, Cambridge, 1(2)

[37] Yamane,T. (1967). Statistics ; An introductory analysis, $2^{\text {nd }}$ edition. New York: Harper and Row

[38] Altheide, D.L and Johnson, J.M (1994) Criteria for assessing interpretive Validity in Qualitative research. In N.K Denzin of Lincoln (eds) handbook of qualitative Research, pp 485-499. Thousand Oaks, CA: Sage.

[39] Sultan, A. (2017). A study on leadership styles executed by principals and academic coordinator in one of the private schools in Gilgit Baltistan, Pakistan. The journal on academic research international, 8 (3)71-78) 